\title{
Evaluation of intellectual capital in a SME in the city of Puebla, Mexico; applying the Skandia model
}

\section{Evaluación del capital intelectual en una PyME en la ciudad de Puebla, México; aplicando el modelo Skandia}

\author{
ORTIZ-CARRANCO, Araceli†, RAMIREZ-ROSAS, José, ARROYO-DIAZ, Salvador and LOZADA \\ LECHUGA, Jorge*
}

Universidad Politécnica de Puebla

ID $1^{\text {st }}$ Author: Araceli, Ortiz-Carranco / ORC ID: 0000-0001-7835-6339, CVU CONACYT ID: 481086

ID $1^{\text {st }}$ Coauthor: José, Ramirez-Rosas / ORC ID: 0000-0003-0664-3843, Researcher ID Thomson: L-9055-2018, CVU CONACYT ID: 502250

ID $2^{\text {nd }}$ Coauthor: Arroyo-Diaz, Salvador / ORC ID: 0000-0003-4970-5450, CVU CONACYT ID: 104369

ID $3^{\text {rd }}$ Coauthor: Jorge, Lozada-Lechuga / ORC ID: 0000-0003-1165-2007, CVU CONACYT ID: 100439

\begin{abstract}
The present article proposes to evaluate the Intellectual Capital (CI) in a Small and Medium Company (SME) located in the city of Puebla applying the methodology indicated by the Skandia model. The focus of the present study is quantitative and qualitative descriptive type; through this approach, the performance on the investment made in an administrative system by the company in the 2017 study year can be observed, with the purpose of improving its processes, controlling them and offering better service to its clients. The methodology followed in this work is the one proposed by the Skandia model, going through its different approaches and calculating the respective indicators according to the information available in the company. In the final part of this paper, the conclusions are presented from two perspectives, the first from the perspective of the managers of the company object of this study and the second from a generalized position for SMEs.
\end{abstract}

Intellectual Capital, Small and Medium Company, Skandia model

\section{Resumen}

El presente artículo propone evaluar el Capital Intelectual (CI) en una Pequeña y Mediana Empresa (PyME) ubicada en la ciudad de Puebla aplicando la metodología señalada por el modelo Skandia. El enfoque del presente estudio es, cuantitativo y cualitativo de tipo descriptivo; mediante dicho enfoque se puede observar el rendimiento sobre la inversión hecha en un sistema administrativo por parte de la empresa en el año de estudio 2017, con el propósito de mejorar sus procesos, el control de éstos y ofrecer mejor atención a sus clientes. La metodología que se sigue en este trabajo es la propuesta por el modelo Skandia, pasando por sus diferentes enfoques y calculando los indicadores respectivos de acuerdo a la información disponible en la empresa en cuestión. En la parte final de este trabajo se presentan las conclusiones desde dos perspectivas, la primera desde la perspectiva de los directivos de la empresa objeto de este estudio y la segunda desde una postura generalizada para las PyME's.

Capital intelectual, Pequeña y mediana empresa, Modelo Skandia

\footnotetext{
* Correspondence to Author (email: jorge.lozada@uppuebla.edu.mx)

$\dagger$ Researcher contributing first author.
} 


\section{Introduction}

Intellectual Capital (C.I.) is an intangible asset that constitutes one of the pending issues in the evaluation within the financial accounting of companies because their contributions of human resources are essential to meet the established goals.

According to the Financial Information Standard (NIF C-8), an intangible asset is that identifiable without physical substance, used for the production or supply of goods or provision of services or for administrative purposes in order to have improvements in the future, so the IC meets this characteristic since the knowledge of the workers of the organizations generates an added value to the organization.

However, although this intangible asset generates added value to organizations, in most cases the value of this asset is unknown, having a restriction for decision-making (Demuner, Saavedra, \& Camarena, 2017).

However, it must be considered that research and ideas related to Intellectual Capital are not new (Dias, Teixeira, Mafra, \& Baroni, 2017, 52 2017), so interest in the subject has been growing as The new economy based on information technologies is extended and from there the knowledge acquired by employees increases so that companies become more competitive (Muñoz, 2019)

In addition to the above, companies have traditionally evaluated their assets, and that is why financial and non-financial models have been used to achieve this purpose; However, the financial value of C.I. For this reason, the knowledge economy has highlighted the importance of collecting the special value of this intangible asset, so multiple methodologies have appeared to measure them (Vidal, 2017).

However, the need to evaluate the C.I. it is born that in the current organizations it is no longer enough to translate the financial reports of their assets, liabilities and results; but also give value to the C.I. that is generated within the organizations for decision-making (Demuner, Saavedra, \& Camarena, 2017).
For Dumay, (2004) states that much remains to be investigated in the field of evaluation of the C.I. Therefore, this brings up classical researchers on the subject such as (Sveiby, 1997), recognizing that traditional performance measures for a company are based on conventional accounting principles, which may be incorrect in a knowledge economy and therefore may lead investors to make bad decisions.

On the other hand, there have been investigations that have reported how C.I. influences. in the case of mergers of companies, especially in the financial sector, which makes the context relevant since, as a result of this merger, the added value of the company increases (Dias, Teixeira, Mafra, \& Baroni, 2017, 52 2017).

Likewise, at the corporate level it has been shown that the companies that supply more C.I. They have a larger size on the board of directors which means that in the decisionmaking process the error can be reduced and thus increase the probability of reaching the established goals (Tejedo, Ferraz, \& Emmendoerfer, 2017).

On the other hand, the need to evaluate the C.I. In a Small and Medium Business (SME) in Mexico, it arises from the circumstance that these economic units represent $72 \%$ of employment and contribute $52 \%$ of the Gross Domestic Product (GDP) (Carriedo, 2017); In this sense, there is a possibility that these economic units may be more competitive attracting investors. The evaluation of the C.I. It tries to motivate financial investments by looking at the knowledge that people in organizations cause in order to meet their goals, contributing to continuous improvement (Pérez, Pelayo, \& Añez, 2016).

In this way, trying to eliminate the obstacles that these economic entities have for their development; This research focuses on the proposal to create a model that allows the evaluation of the C.I. of an SME based in the City of Puebla, allowing to reflect the financial valuation for decision-making in the organization, based on an analysis of the different valuation models of the C.I. landing on the situation of the company under study, through indicators to establish a financial value applying the Skandia model. 
In relation to this study, it consists of six parts, in the first one the theoretical framework of the subject is presented where various concepts of intellectual capital will be exposed as well as the context of SMEs in Mexico; In the second part, emphasis will be placed on the problem statement; part three will detail the objectives of the investigation; part four will analyze the methodology and model used to carry out the research; in part number five the case study will be analyzed so that later, in the last part the results of the present investigation are discussed.

\section{Theoretical framework}

\section{Intellectual Capital}

The CI. It is an intangible asset of organizations whose main characteristic is to generate value to them (Barney, 1991), in this way the C.I. it constitutes the basis of the competitive advantage of the company, especially that capital related to the internal capacities developed by the companies and that due to their particular characteristics are difficult to copy and imitate making them unique. Pacheco (2009), defines C.I. as individual or collective knowledge that produces value, it is the main source of wealth for professions and organizations in the knowledge society.

Hence the C.I. It can be defined as the administrative process applied to the growth and conservation of effort, experiences, knowledge, and skills, occupying the growth and development of people so that they can reach higher levels of fitness, creativity and achievement given that individuals are the main resource of any organization (Jacobo, Leyva, Daniel, \& Mendoza, 2019).

For Scarabino, Biancardi, \& Blando (2007) define C.I. as the set of intangible resources of the organization that have the capacity to generate value either in the present or in the future, allowing to recognize it through the accounting norm the skills, or abilities of the workers; by its nature the C.I. It is also divided into Human Capital, Structural and Relational, which generate the knowledge and learning of people as a result of their training. Likewise, human capital is the intangible resources that people have to generate value, it is identified by the skills, knowledge and abilities that workers have when doing their work (Bueno, Salmador, \& Merino, 2008).
On the other hand, structural capital is the infrastructure that helps to incorporate, train and maintain human capital (Scarabino, Biancardi, \& Blando, 2007), that is, this capital must be aligned with the corporate philosophy of development organizations adequate of their tasks, in summary this knowledge is acquired over time since the more the individual permeating in the organization, the more he will have how to do things within the organization.

In turn, relational capital is the sum of human and structural capital whose purpose is to incorporate knowledge in an integral way to the organization, that is, to the company's suppliers, customers and workers in order to expedite the tasks of the organization.

However, in each capital the particular objectives must be taken into account so that together they can contribute to the intellectual capital and thus achieve the objectives set by the organizations (Marin, 2001), as shown in figure number 1 .

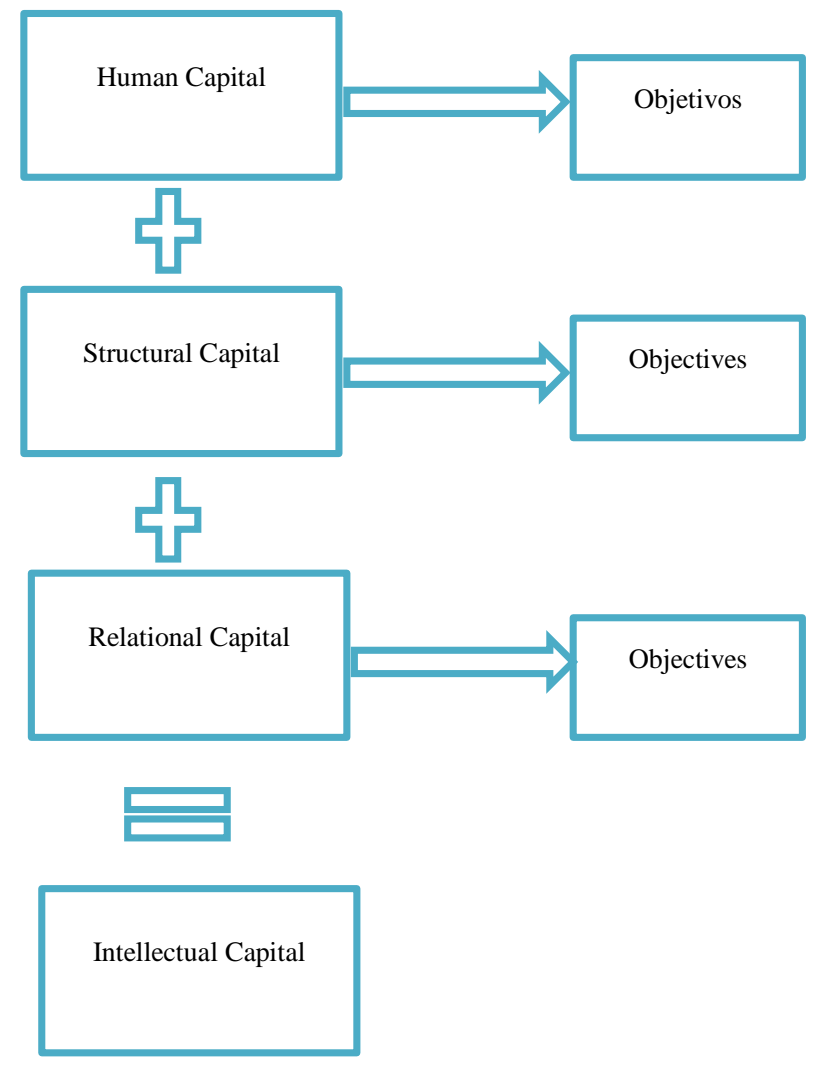

Figure 1 Components of Intellectual Capital Source: Elaboration: based on (Marin, 2001)

As can be seen in Figure number 1, the conjugation of human, structural and relational capital results in intellectual capital which brings added value to an organization. 
However, in order to achieve this result, the aforementioned will have to meet certain objectives measured in indicators. Finally, once the indicators have been implemented to evaluate the C.I. it would be verified if the objectives of the organization were achieved.

\section{Evaluation Model for Intellectual Capital "Skandia"}

In terms of evaluation models for intellectual capital, the best known are the following: Intellectual Asset Monitor, Strategic Management by Competencies, Nova and Skandia Navigator. Due to the above, this research project will be based on the model called Skandia Navigator.

In 1991 Skandia Assurance and Financial Services (AFS) hired Leif Edvinson, who raises how it is possible for a company to invest in human capital and technology since in the short term it suffers damage to the profit and loss accounts by reducing the value of balance and book value, so it is necessary to build a new valuation system; a short time later the market value of an organization is established, which is determined by its financial capital and intellectual capital. (Leif Edvinsson, 1998).

In 1996, Skandia standardized an intellectual capital model called "Value Creation Processes", focusing its attention on the growth of organizational capital. The Skandia Navigator is considered as one of the most important tools for measuring intellectual capital, as it represents a history of how knowledge economy was obtaining meticulous results on the capacity and power of an organization to transform intellectual capital into financial capital. (Edvinsson L. and., 1998).

Zuluaga (2019) says that the IC within an organization is considered as an intangible asset giving results that benefit it, so that it becomes financial capital through accounting transforming and adapting the IC as a new concept, also generating connection between the market in relation to customers, suppliers, experience, new knowledge, organizational technology, professional skills, and skills.
A company always seeks to have a competitive advantage through organizational change by showing itself in 3 different ways: technological, internal and external, reflecting on knowledge which is considered an essential resource to achieve positive results in the economic activity of an organization through of organizational intelligence; In this way, people who perform their assigned tasks are called intelligently taking into account investors (those who contribute capital or funds), managers (distributors of resources) and employees (perform specific functions) thus giving importance to Intellectual Capital (Jama, 2019)

For its part, the Skandia model states that all this only works if knowledge is shared within the organization, is located in its goals, and the time between receiving the information and application is continuously reduced. (Edvinsson L. y., 1998)

\section{Elements of intellectual capital in the Skandia model}

In the case of Skandia in 1991, he proposes the Skandia Value Scheme, to demonstrate that intellectual capital is formed as follows:

- Human capital.

- $\quad$ Structural capital, which is divided into:

a) Customer Capital

b) Organizational capital.

The elements that make up the intellectual capital that generate a competitive advantage are the following, according to each of the authors: addressed:

First, Edvisson and Mallone will be

Human capital: It is made up of the abilities, knowledge, skills, abilities and experience of the employees and managers of an organization.

Structural capital: It is made up of the capital called "clientele" and "organizational" capital.

Client capital: Reflects the recognition that the company has towards its loyal customers, usually under the heading called "goodwill". 
Organizational capital: Refers to the infrastructure sustained by human capital making possible the proper functioning of the company. This is included in the corporate culture, computer or communication systems, databases and management methods.

Thus, intellectual capital encompasses a series of elements so extensive that they range from assets included in the financial statements to resources that are difficult to recognize and measure (level of customer loyalty, relationships with suppliers, etc.).

\section{Human capital}

However, intellectual capital is a resource or asset that generates value within an organization, since human capital is considered as the capacity that a person has to adapt to changes and learn constantly using his talent; That is why companies strengthen learning and creativity in their staff. Where this is how human capital is defined, which is the set of intangible resources that members of an organization possess (Roos J, Roos G, Dragonetti N and Edvinsson, 2001); According to Roos, resources can be classified as follows:

A. Skills: Conformed by knowledge, skills, abilities and know-how.

B. Attitude: Refers to motivation and leadership capacity.

C. Intellectual agility: All those skills of the members of the organization to be quick mentally taking into account innovation and entrepreneurship, as well as the ability to adapt and create synergies, among others.

Within a company, human assets are considered of utmost importance since they are those that support the organization and respond to the needs of the market; that is, when the company is going through a difficult time it is there that human capital is capable of generating new strategies, products, services and technologies to enhance the company. (Brooking A., 1997) mentions that, human assets are capable of promoting and responding to the needs of the market, generating a set of competences associated with work, defined as a mixture of techniques, creative features, personality attributes, professional qualifications; in addition to the following points:

\section{Structural Capital.}

Referring to structural capital, it can be conceived as all those equipment, patents, programs, or tools that help employees increase their productivity, as well as all the relationships that the company has with its customers (Vidal, 2017).

\section{Customer Capital.}

Most authors call this factor as clientele capital or relational capital, since this type of capital has to do with the actions or relationships that the company performs to strengthen its ties with external actors taking into account not only its customers but also, to its suppliers, investors, financial institutions, new potentials and shareholders. On the other hand, Leandro Cañibano (Mesquita \& Cañibano, 2006) calls it relational capital, defining it as "the one that has to do with customers, customer loyalty and satisfaction, maintaining good relationships and distribution agreements, franchises, licenses, etc.".

For Kaplan and Norton, it is "the customer perspective that allows identifying the customer and market segments in which the business unit will compete to articulate the market-based strategy that will provide future financial returns of a higher category". (Kaplan \& Norton, 1992)

\section{Organizational Capital}

It is also known as structural capital (EC), which includes all those elements of internal organizational type that the company puts into practice to perform its functions in the most optimal way possible using different tools such as: databases, tables organizational, process manuals, individual property (patents, trademarks or any intangible element that is protected by intellectual property rights) and all those whose value is greater than the material value of the company. 
In other words, organizational capital (CO) or structural capital is that which includes the work processes, techniques, methods and programs that are used by human resources allowing them to increase the efficiency of their activities within each area of work in the company ( Alarcón, Freire, Pérez, Frías, \& Nogueira, 2019)

Drucker, quoted by Stewart himself, points out that "only the organization can provide the fundamental continuity that the intellectual worker needs to be effective. Only the organization can convert the specialized knowledge of the intellectual worker into performance". (Drucker \& Stewart, 2005)

The C.O. It includes elements such as inventions, data, publications and processes that can be patented, that is, they are subject to legal property rights, but it should be emphasized that, not only do these elements make it up, but it also includes "strategy and culture, structures and systems, routines and procedures that are usually more important and valuable than codified goods ". (Edvinsson L., 1997)

\section{Structure of the Skandia model}

The Skandia Business Navigator proposes five approaches such as: A) Financial approach, b) Customer or customer focus, c) Process approach, d) Development and innovation approach and Human focus.

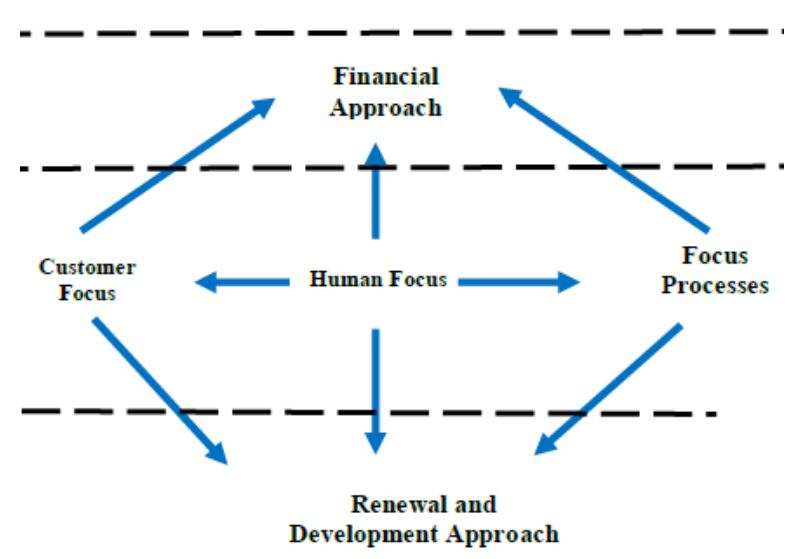

Figure 2 Approaches of the Skandia Business Navigator Source: (Ascanio A., 1992.1996)

\section{Financial Approach}

This approach refers to the past whose integration is made up of the annual accounts and management reports.
Therefore, it is necessary to have an effective financial capitalization to analyse, measure and provide information on how the company operates. That is why Skandia proposes financial capital indicators that highlight the most valuable assets within a company, detecting 4 types of indices through a pattern that are:

1. Cumulatives: Effective to discover those points of change during the life cycle stages.

2. Competitives: It compares the performance that the company has with that of the entire industry, expressing it as a percentage or through indices.

3. Comparatives: Includes two or more variables within the company to analyze them.

4. Combined: They are used to obtain a short, medium- or long-term perspective on the performance in an organization.

1. Financial Assets (\$): Also known as Fixed Assets, they are all those that can be measured within the organization.

2. Financial Assets / Employees (\$): They reflect the efficiency in the use of these assets by each employee.

3. Income / Employees (\$): Monetary average of what each employee provides to the company for its sales made.

4. Managed Income / Assets (\%): For each managed asset how much will be obtained from income or sales.

5. Income from insurance premiums (\$): These are all insurance premiums that are sold.

6. Income / Premiums from new businesses (\$): Measurement of income and regeneration, makes it possible to have an idea of how the company is likely to behave in future years.

7. Billing / Employees (\%): This indicator reflects the sales that each employee has.

8. Client time / Employee attention (\%): It can be obtained with the indicator "client time" / person-income, it serves as immediate feedback to detect weaknesses and strengths, in addition to setting new goals in the organization.

9. Insurance Activity / Employee Result (\$): Indicates how many insurances each employee is selling. 
10. Proportion of losses compared to market average (\%): Creates a percentage or customer loyalty ratio.

11. Return on equity (\%): Also known as direct return and refers to the gross margin which is obtained from gross profits between sales.

12. Benefits of ordinary activities (\$): Also known as "Net operating income" and refers to the income that is received directly from the insurance and financial services business.

13. Market value (\$): It is the book value multiplied by the number of shares.

14. Market / employee value (\$): It indicates the added value of the human resource.

15. Return on the net value resulting from the expense in a new business (\%): It is the return on investment better known as ROI.

16. Return on net asset value (\$): These are the profits resulting from a new business.

17. Value added / Employee (\$): Skandia points out that this is the most important indicator of this group since it is the least distorted by accounting.

18. Computer expenditure / Administrative expenditure (\%): Refers to how much of the administrative expenses corresponds to the computer expenses.

19. Value added / employed in computer science or administrative (\$): Relationship between employees and computer technology to add value to the firm.

20. Investments in information technology (\$): How much is being invested for technological development in information technology.

\section{Customer Focus}

This approach is made up of all those measures that capture the reality of the relations between the company / client, these indicators must cumulatively capture the flow of relations between the company and its clients (current and potential) such as: type of client, duration of the relationship of the client, role or role of the client in the company, customer support, among much more; but the Skandia model presents the following fundamental indicators for this approach and they are: (Nevado D, López V, 2002):
1. Market share (\%): Represents how well the entity is positioned and reflects customer satisfaction.

2. Number of current customer accounts (\#): Reflects the variation in the demand for goods and services.

3. Lost customers (\#): Measure that reflects a loss for the company represented in time and money invested in a customer and future lost revenue.

4. Telephone accessibility (\%): System capable of maintaining an efficient relationship between client and organization or in some cases unoccupied telephone lines for customer service.

5. Annual Sales / Customers (\$): Reflects the importance of certain clients within the organization.

6. Measured duration of relationship with the client (\#): How loyal the client has been within the entity and if it has new clients, helping to monitor its behavior in the future.

7. Customer score (\#): How customers view the organization for its services from 0 to 10 .

8. Customer visit to the company (\#): How important is the organization to the visits of its customers and if they provide recommendations in the development of the product.

9. Days dedicated to visiting customers (\#): Importance of dedicating time to the client and in the future being a factor of change in the consumption of products or services.

10. Customers / Employees (\#): How many people are in charge of customer service.

11. Average time between contact with customer and sale (\#): Time to make the sale after meeting a potential customer.

12. Customer satisfaction (\%): Constant communication through surveys conducted by the organization to know customer satisfaction.

13. Point of sale (\#): Number of branches.

14. Frequency of repetition on customer purchases (\#): How many customers have re-hired the services or products of the organization.

15. Investment in information technology (\$): How much the company invests in issues of technological development in information technology. 
16. Support Expense / Client (\$): How much the entity has invested in support of its customers.

17. Spending on service / client / year (\$): How much the company has spent to provide a service per year.

18. Employees dedicated to customer service (\#): Basic indicator for personalized customer service.

19. Profitability per client (\$): Identifies the ability of each client to provide greater profits to the organization.

These measures are the most important for investors, since they allow to know their client portfolio and the relationship between company-client, in this way they will help to make strategic decisions.

This approach focuses on the technological role that is used as a tool to sustain the company and create value, helping to increase its efficiency and productivity. It is considered important as it is an element that helps the electronic exchange of data, web pages, inventory networks and new relationships between the organization, suppliers, partners and customers that are fundamental parts to survive in such a competitive market. (Nevado D, López $\mathrm{V}$, 2002).

On the other hand, we must take into account the possible technological problems that arise in this approach when generating value:

1. Wrong technology: Choosing a wrong technology can be a very serious problem for the organization, since adopting a new invention can bring infinite risks when creating a new product.

2. Wrong supplier: Choosing a wrong supplier causes greater problems and in the long run it can be very expensive, since when you buy some machinery it can disappear or distribute incorrectly by giving discontinued parts or systems that cannot be to update.
3. Wrong applications: In this part we find the technology that is purchased, whose objective is to solve problems quickly and easily. Buying technology in large quantities for the simple fact that the brand has been good does not mean that this will solve the problems in the organization. All this machinery is considered as assets; however, in real life they are passive because of the damage they can cause in productivity and capital.

4. Wrong philosophy: Most companies only care about having cutting-edge technology leaving aside the goals or objectives of the organization, in addition to the strategies to attack their competition; That is why it is necessary to create a suitable model that allows to assess the technology correctly within the balance sheet.

The solution to avoid falling into these errors is to create indexes that allow detecting errors within the technological infrastructure; some of these indexes are:

- Value useful technologies that contribute to the value of the firm.

- $\quad$ Monitor the vendor's support and age for the company's process technology

- Measure the performance of the process and the real contribution it has in business productivity.

- Incorporate performance indices in relation to the fulfillment of established goals within the processes.

Next, the process indicators that Skandia proposed are listed:

1. Administration expenses / assets managed (\$): How much the assets generated are generated from expenses.

2. Administration expense / Total income (\%): Of the total income the organization receives, how much is spent on administrative expenses.

3. Cost of administrative errors / administrative income (\%): How much does a mistake made within the organization cost?. 
4. Productivity rate in relation to that of the industry (\%): This index is obtained according to information granted by organizations in each sector.

5. Total performance compared to the previous year (\%): Earnings compared to the previous year,

6. Contracts registered without errors (\#): Those contracts that are executed correctly.

7. Personal Computers / Employees (\#): How efficient are personal computers for the number of employees there are.

8. 8.- Administrative expense / Employees (\$): Expense incurred by human resources within the organization.

9. Expenditure on computer technology (IT) / Employees (\$): How many of the employees are assigned software and hardware to perform their daily activities.

10. Expenses in IT / Administrative Expense (\%): Participation of IT in administrative expenses.

11. IT Staff / Total Personnel (\%): How many employees are dedicated to the IT department.

12. Employees working at home / Total employees (\%): Future of telecommunications, as well as checking the efficiency of technology and research.

13. Corporate quality goal (\#): This index is defined by the company according to the characteristics of the market.

14. Corporate performance / Quality goal (\%): Defines how close or far the organization is from its objectives or goals.

15. Sales / Employees (\$): It is detected through this index which employee makes the highest sales.

\section{Renewal and Development Approach.}

It captures the units that define the company, these are part of the clients (habits, changes, etc.), in the market (investment, market research, target markets, etc.), in the strategic partners (investments, communication, etc.), in infrastructure (acquisitions) and in employees (level of training or learning, goals, motivation, etc.). This approach represents failures, needs to be covered, weaknesses, barriers, among others that the company must take into account so that it does not happen in the future (Nevado D, López V, 2002).
Skandia proposed the following indexes within this approach:

1. Index of satisfied employees (\#): The satisfaction and possible needs that the employee has within the company is identified.

2. Marketing expenditure / Managed assets (\$): How much the company invests to publicize its products in the market.

3. Participation in training hours (\%): Of $100 \%$ of the employee's time, how much of this one goes to training.

4. Participation in hours of development of new products $(\%)$ : Of $100 \%$ of the organization's time, how much it dedicates to the relation of new products.

5. R\&D expenses / Administrative expenditure (\%): How much of the administrative expenses are invested in research and development expenses.

6. Expenditure on training / Employees (\$): For each employee how much is allocated for their development within the organization.

7. Expenditure on training / Administrative expenditure (\%): How much of the administrative expenses is invested for employee training.

8. New business development expense / Administrative expense (\%): How much of the administrative expenses is invested to develop new businesses.

9. Proportion of employees under 40 years (\%): Of the total human resources, how many of them are under 40 years of age?

10. Development expenditure on technology and research / Total expenditure on IT (\%): How much of the total technology expenses is invested for the development of technology and research.

11. R\&D Resources / Total Resources (\%): Amount of resources used for innovation and development

12. Average customer age (\#).

13. Average education in employees (\#).

14. Average income (\$).

15. Average duration of the client in the organization, months (\#).

16. Investment in education / Client (\$): How much of the income is invested so that the client knows more about the product and knows how to use it. 
17. Direct communication with customers / Year (\#): Refers to how many times in the year there has been direct dealings with customers.

18. Investment in development of new markets (\$).

19. Investment in structural capital development (\$): How much is invested in software, hardware, patents, brands, and fixed assets that help employees perform their tasks.

20. Value of the electronic data exchange system (\$): Refers to the investment made on the internet and the necessary equipment for virtual meetings.

21. Proportion of new products (\%).

22. Research and development invested in product design (\%).

23. Company's average age of patents (\#).

24. Patents pending (\#).

\section{Human approach}

This approach is one of the most difficult to measure, since the competence of employees in relation to working methods is very different; nevertheless, Skandia did it by setting the basic and main measures for productivity in employees and managers, in relation to infrastructure, he applied it to help employees perform their day-to-day tasks better, in order to identify changes produced and establish common techniques to measure them. Next, Skandia proposes the following indicators (Nevado D, López V, 2002):

1. Leadership index (\%): This includes employees who have leadership in their areas.

2. Motivation index (\%): Employees who are satisfied, motivated and competent.

3. Index of qualified employees (\#): Those who have Bachelor's degrees, Diplomas, Masters and Doctorates.

4. Number of permanent full-time employees (\#): It includes the majority of office workers, tele-employees (remote workers), company employees, managers and mid-level executives.

5. Percentages of managers of nationalities other than the company's headquarters (\%): Global competition, international administration creating competitive advantage.

6. Employee turnover (\%): Critical factor for a company.
7. Average years of services in the company (\#): Personnel turnover is very important and through this index the average duration of employees is displayed.

8. Number of managers or managers (\#): People who have a manager position.

9. Number of women managers (\#): Women who have management positions.

10. Training / Employee Expense (\$): Measures the company's commitment to keep its employees happy and up to date by means of workshops or trainings.

11. Average age of employees (\#): Youth in some cases cannot be an advantage. The transmission of the corporate philosophy is best done by older employees.

12. Proportion of employees under 40 years (\%): Measure that reflects how the organization updates its staff.

13. Training time days-year (\#).

14. Number of staff members (\#): Workers, employees, among others.

15. Average duration of contracts (\#): According to company policy.

16. Percentage of expert employees (\%): Identify expert personnel in each specific area.

17. Education level indices (\#): How prepared the employee is.

18. Value added by employee (\%): Participation that the employee has within the company to generate added value.

On the other hand, the Skandia model developed by the insurance and financial services company of the same name is an instrument capable of measuring in a practical way and with financial and non-financial indicators the C.I. in a way that allows you to visualize the organization quickly, helping them to make appropriate decisions (Saavedra \& Saavedra, 2012)

This model has a five-area approach based on the financial approach, passing through the clientele and process approach, then entering the renewal and development approach so that in the end it ends in the human approach.

The financial approach represents the historical monetary data of the organization, in this way you can identify the guidelines to be followed by the indicators established for the calculation of the value of the C.I. 
On the other hand, the clientele and process approach represents the present and the activities of the company that are oriented towards the intangible asset, in this context although it does not focus on monetary situations, it is focused on the acts that the collaborators perform with the clients and on the processes to identify the indicators to be measured.

In the renewal and development approach are the training given to workers, the development of new products, strategic actions as well as the markets in which the organization will operate.

Finally, the human approach symbolizes the capacity and intelligence that they grant and apply to the entity, in this sense an added value is given to the organization, it is the difference that can exist with other organizations due to the constant development of the staff.

The equation that Skandia proposes regarding the measurement of C.I. is the next:

$$
\text { C.I. }=i * C
$$

Where:

$\mathrm{C}=$ Value of intellectual capital in monetary units.

$\mathrm{i}=$ Efficiency coefficient with which the organization is using said capital.

Now to determine the efficiency coefficient is determined as follows:

$i=(n / x)$

Where:

$\mathrm{n}=\mathrm{It}$ is the sum of the decimal values of the nine efficiency indices.

$\mathrm{x}=$ Is the number of these indices.

\section{SMEs in Mexico}

Small and Medium Enterprises (SMEs) constitute in Mexico with $99 \%$ of the total economic units, representing $52 \%$ of the Gross Domestic Product (GDP) constituting 72\% of formal jobs (Ministry of Economy, 2009), being thus one of the most important factors for Mexico since these economic units generate an impact on the economy.
For an organization to be SMEs, it will have to observe the stratification of SMEs which, in relation to the sector, range of number of workers and annual sales range, as described in figure number 2 .

\begin{tabular}{|c|c|c|c|c|}
\hline Size & Sector & $\begin{array}{l}\text { Range } \\
\text { of } \\
\text { number } \\
\text { of } \\
\text { workers }\end{array}$ & $\begin{array}{l}\text { Annual } \\
\text { sales } \\
\text { amount } \\
\text { range } \\
\text { (mdp) }\end{array}$ & $\begin{array}{l}\text { Maximum } \\
\text { limit } \\
\text { changing * }\end{array}$ \\
\hline Micro & All & Up to 10 & $\begin{array}{l}\text { Up to } \$ \\
4\end{array}$ & 4.6 \\
\hline \multirow[t]{2}{*}{ Small } & Commerce & $\begin{array}{l}\text { From } 11 \\
\text { to } 30\end{array}$ & $\begin{array}{ll}\text { From } & \$ \\
4.01 & \text { to } \\
100 & \end{array}$ & 93 \\
\hline & $\begin{array}{l}\text { Industry } \\
\text { and } \\
\text { Service }\end{array}$ & $\begin{array}{l}\text { From } 11 \\
\text { to } 50\end{array}$ & $\begin{array}{l}\text { From } \$ \\
4.01 \text { to } \$ \\
100\end{array}$ & 95 \\
\hline \multirow[t]{3}{*}{ Medium } & Commerce & $\begin{array}{l}\text { From } 31 \\
\text { to } 100\end{array}$ & \multirow{2}{*}{$\begin{array}{l}\text { From } \$ \\
100.01 \\
\text { to } \$ 250\end{array}$} & \multirow[t]{2}{*}{235} \\
\hline & Services & $\begin{array}{l}\text { From } 51 \\
\text { to } 100\end{array}$ & & \\
\hline & Industries & $\begin{array}{l}\text { From } 51 \\
\text { to } 250\end{array}$ & $\begin{array}{l}\text { From } \$ \\
100.01 \\
\text { to } \$ 250\end{array}$ & 250 \\
\hline
\end{tabular}

Table 1 Stratification of SMEs in Mexico Source: (Ministry of Economy, 2009)

However, these economic units represent great challenges to be able to develop properly, according to (González, Solís, \& Alcudia, 2010) SMEs face problems such as time for their production processes, human resources, supplies, machinery and financial resources.

On the other hand (Estrada \& Heijs, 2005) say that the problems that SMEs face are innovative in nature that are linked to the staff of organizations, since new ideas arise from innovative ideas, however this burden is focused on the CI since derived from all the knowledge is reflected in the productive profitability of the entities.

Added to this is that the C.I. In SMEs it is valued from the strategic point of view, that is, in the decision-making process to increase their development, this is because SMEs do not invest in this concept leaving behind the capabilities of their collaborators to generate a added value and thus be more competitive in the market. On the other hand (Estrada \& Heijs, 2005) say that the problems that SMEs face are innovative in nature that are linked to the staff of organizations, since new ideas arise from innovative ideas, however this burden is focused on the CI since derived from all the knowledge is reflected in the productive profitability of the entities.

ORTIZ-CARRANCO, Araceli, RAMIREZ-ROSAS, José, ARROYODIAZ, Salvador and LOZADA LECHUGA, Jorge. Evaluation of intellectual capital in a SME in the city of Puebla, Mexico; applying the Skandia model. Journal-Microeconomics. 2019 


\section{Problem Statement}

The Intellectual Capital of the organizations has been approached with great presence in the organizations to such an extent to know what the performance on the continuous processes of the companies has been. A primary factor that companies have had is the same performance in relation to the new technologies that have been acquired in order to improve their work.

In this sense, the organization under study has considered the performance on the acquisition of a new administrative system that allows it to improve its inventory purchase and sale processes, this with the objective of making more accurate decisions about training of staff to achieve full compliance with their customers.

For this reason, the use of the Skandia model was proposed since it was found adequate to measure the performance of the personnel on the investment of the administrative system, allowing the valuation of the investment in training as in infrastructure relating it to the staff and clients of the same organization.

\section{Research objectives.}

The objectives of the present investigation are the following:

A. Know the staff efficiency index on the administrative system that the organization acquired.

B. Know what are those indicators that have to work to reach an efficiency rate of $100 \%$

C. Know the value of intellectual capital on the new administrative system acquired by the organization.

\section{Methodology}

This research work has the characteristic of being a mixed study, since it is quantitative in order to obtain results that will offer a point of view on the phenomenon of C.I. about the company under study and qualitative since the data obtained will be characterized on the circumstances of the company (Hernández, Fernández, \& Pilar, 2004)
A. It is descriptive to have the tendency that derived from the results it will offer a real panorama in comparison with the financial results of the organization whose fundamental objective is the decision making in the term of the C.I.

B. On the other hand, the case study the methodology to evaluate the C.I. The following steps were used to determine the qualitative indicators of the company: 1.- The investment made by the organization in terms of training workers to use the new administrative system was identified; 2.- The investments made by the company in the administrative system and new technologies acquired were identified; 3.- Those indicators that were related to the administrative system were identified and 4- The value of intellectual capital over the new administrative system was calculated.

C. Once the foregoing has been determined, the indicators will be classified to expose them in the structural, human and relational Capital so that the calculation of the C.I can be determined later.

\section{Case study}

The company under study is a Small and Medium Business (SME) incorporated as a Public Limited Company whose location is in the City of Puebla, Mexico has 42 workers whose activity is the pharmaceutical industry, due to its processes the economic entity, has been raised determine the value that your staff has helping to make decisions regarding financial results especially on the administrative system that was acquired.

For this, the investments made by the company in 2017 were identified, of which the training and training of personnel with a value of \$150,000.00 (Human Focus) was identified, as well as the direct investment in assets with a total amount of $\$ 750,000.00$ (Investment and Development Approach) as described in Table No. 2 and 3 respectively. 


\begin{tabular}{|l|r|}
\hline \multicolumn{1}{|c|}{ Human approach } & \multicolumn{1}{|c|}{ Year of study } \\
\hline 1.- Investment in training & $\$ 150,000.00$ \\
\hline Total & $\$ 150,000.00$ \\
\hline $\begin{array}{l}\text { Table No. 2 Investment in Human and Structural } \\
\text { Capital by the company. Source: self made. }\end{array}$ \\
\hline $\begin{array}{l}\text { Investment and development } \\
\text { approach }\end{array}$ & Year of study \\
\hline $\begin{array}{l}\text { 1.- Investment in administrative } \\
\text { systems }\end{array}$ & $\$ 250,000.00$ \\
\hline $\begin{array}{l}\text { 2.- Investment of machinery and } \\
\text { technology }\end{array}$ & $\$ 500,000.00$ \\
\hline Total & $\$ 750,000.00$ \\
\hline
\end{tabular}

Table 3 Investment and development approach Source: Own Elaboration

From the investment in the training of the staff, it was verified that the trainings were in accordance with the profiles and tasks of the workers, also comparing them with the documents that supported said training that was based on an integral administrative system that (structural capital) to be more efficient internal processes of the organization. Once the human and structural capital was identified, the indicators were worked on to obtain the investment of the relational capital, which were classified into six indicators.:

A. Customer satisfaction: Surveys were conducted where the main objective was to verify whether the company's potential customers were satisfied with the attention of the organization under study, based on the implementation of the administrative system, the company's satisfaction rate for the 2017 was 0.85 .

B. Purchases related to the new administrative system: This indicator is identified with the purchase of products based on the use of the new administrative system, that is, knowing how the new operations are developed, the index obtained by this indicator was 0.75 .

C. People with university degree: This indicator is related to workers who already have a knowledge of university degree in relation to the universe of existing workers in the entity (42), this index was 0.60 for the company.

D. Compliance with objectives by the company: This indicator evaluates the objectives obtained from the workers which was 0.90
E. Personnel turnover: This indicator measured the output of company personnel in the sense that they will look for better job offers, so that in the year of study a rotation index of 0.10 was obtained.

F. Personnel satisfaction: This indicator is related to the previous one, that is to say, not having such a significant turnover, it is understood that employees can be satisfied with their work, so in this index a factor of 0.80 was obtained

In this way the indicators identified above are determined in the investment of relational capital as shown in table No. 4

\begin{tabular}{|l|r|}
\hline \multicolumn{1}{|c|}{ Customer Focus } & \multicolumn{1}{|c|}{$\begin{array}{c}\text { Year of } \\
\text { study }\end{array}$} \\
\hline 1.- Customer Satisfaction Index & 0.85 \\
\hline $\begin{array}{l}\text { 2.- Purchase index related to the } \\
\text { administrative system }\end{array}$ & 0.75 \\
\hline 3.- Index of people with university degree & 0.60 \\
\hline $\begin{array}{l}\text { 4.- Index of fulfillment of the objectives } \\
\text { by the organization. }\end{array}$ & 0.90 \\
\hline 5.- Staff turnover rate & 0.10 \\
\hline 6.- Staff satisfaction index & 0.80 \\
\hline Total & 4.00 \\
\hline Number of indicators & 6 \\
\hline Efficiency index & .66 \\
\hline
\end{tabular}

Table 4 Customer focus Source: Own Elaboration

Once the investment of human, structural and relational capital was determined, the value of the intellectual capital of the company was calculated, as described in table N. 5.

\begin{tabular}{|l|r|}
\hline \multicolumn{1}{|c}{ Concept } & \multicolumn{1}{c|}{ Amount } \\
\hline $\begin{array}{l}\text { Total investment in human and } \\
\text { structural capital. }\end{array}$ & $\$ 900,000.00$ \\
\hline Efficiency Index & .66 \\
\hline Intellectual capital & $\mathbf{\$ 5 9 4 , 0 0 0 . 0 0}$ \\
\hline
\end{tabular}

Table 5 Calculation of the intellectual capital of the company

Source: Self Made

\section{Conclusions}

With respect to the case study presented, it can be noted that the lowest indicators by the relational capital were the purchase index with a value of 0.75 related to the administrative system and the index of personnel with university degrees with a value of 0.60 . 
Proposing on the part of the managers, they stated that the first indicator can be modified as a result of the first year of implementation of the administrative system and the second indicator proposed that it be evaluated by workers' skills and performance.

The discussion by the directors of the company was the decision making not by the human and structural capital but by the relational capital, since they believe that by modifying the aforementioned indicators through measurable objectives, greater performance can be achieved.

As you can see the value of intellectual capital represents a proportion of what represents the investment of human and structural capital by $66 \%$, which represents the efficiency index, that is, through the qualitative indicators that were identified in capital Relational demonstrates the operability of workers on said investment made by the company to improve its processes.

On the other hand, for an SME to calculate the value of its intellectual capital through the Skandia model is relatively simple through the approaches proposed by the model; this incorporates financial capital into accounting capital; given that the sum of both (accounting capital and intellectual capital) reflects in financial terms the value of a company; which means that a company of this type may be correctly accounting for its tangible and intangible assets, so these companies may be better valued and more attractive to some investors.

\section{References}

Alarcón, M., Freire, L., Pérez, O., Frías, R., \& Nogueira, D. (2019). Medición del rendimiento del Talento Humano en Instituciones de Educación Superior: producción científica. Ingeniería Industrial, 24-36.

Annie Brooking. (1996). Capital Intelectual . Thomson.

Ascanio A. (1992.1996). Modelo Navegador de Skandia . Retrieved from http//:ascanioblogspot.com/2007/05-Navigatorde-skandia-edvinsson-1992.html

Barney, J. (1991). Firm resources and sustained competitive advantage. Journal of Management 17(1), 99-120 doi:10.1177/0149206391.

ISSN-On line: 2531-2987

RINOE $^{\circledR}$ All rights reserved.
Brooking A. (1997). El principal activo de las empresas del tercer milenio. Barcelona: Paidós.

Bueno, E., Salmador, M. P., \& Merino, C. (2008). Génesis, concepto y desarrollo del capital intelectual en la economía del conocimiento: una reflexión sobre el Modelo Intellectus y sus aplicaciones. Estudios de Economía Aplicada, 26 (2), 43-63. Disponible en:

http://redalyc.uaemex.mx/src/inicio/ArtPdfRed. jsp?iCve $=30113187003$.

Carriedo, C. (2017, abril 11). Forbes México. Retrieved from https://www.forbes.com.mx/pymes-mexicanasy-su-estrategia-para-2017/

Demuner, M. d., Saavedra, M. L., \& Camarena, M. E. (2017). Medición del capital intelectual en el sector bancario; aplicación de los modelos Skandia y VAIC. Revista Innovar Journal, 27(66), 75-89, http://dx.doi.org/10.15446/innovar.v27n66.667 12. Retrieved from http://dx.doi.org/10.15446/innovar.v27n66.667 12

Dias, R., Teixeira, V. L., Mafra, F. C., \& Baroni, R. (2017, 52 2017). Intellectual capital in mergers and acquisitions: a case study in a world-class. Revista de Administração, 268-284, http://dx.doi.org/10.1016/j.rausp.2017.05.007.

Drucker, P., \& Stewart, F. (2005). The new society of organizations. Harvard Business Review.

Dumay, L. (2004). The intellectual capital performance of the Japanese. Journal of Intellectual Capital, 5(1), 92-115. doi:10.1108/14691930410512941.

Edvinsson L. (1997). Developing Intellectual Capital At Skandia. Long Range Planning.

Edvinsson, L. y. (1998). El capital intelectual. Barcelona: Gestión 2000.

Edvinsson, L. y. (1998). El Capital Intelectual . Bogotá: Norma.

Estrada, S., \& Heijs, J. (2005). Comportamiento Innovador y Competitividad: Factores explicativos de la conducta exportadora en México. El caso de Guanajuato. Problemas del desarrollo 36(143), 113-143.

ORTIZ-CARRANCO, Araceli, RAMIREZ-ROSAS, José, ARROYODIAZ, Salvador and LOZADA LECHUGA, Jorge. Evaluation of intellectual capital in a SME in the city of Puebla, Mexico; applying the Skandia model. Journal-Microeconomics. 2019 
Funes, Y., \& Hernández, C. (2001). Medición del Valor del Capital Intelectual. Contaduría y Administración (203), 45-58.

González, J., Solís, R., \& Alcudia, C. (2010). Diagnóstico sobre la planeación y control de proyectos en las PYMES de construcción. Revista de la construcción, 9 (1), 17-25, http://dx.doi.org/10.4067/S0718-

915X2010000100003 .

Hernández, R., Fernández, C., \& Pilar, B. (2004). Metodología de la Investigación. México: Mc Graw Hill.

Jacobo, C., Leyva, B., Daniel, Y., \& Mendoza, M. d. (2019). La influencia del capital intelectual en el desempeño organizacional en empresas turísticas de México. Revista Interamericana de Ambiuente y Turismo, 72-81. dx.doi.org/10.4067/S0718-

235X2019000100072.

Jama, V. (2019). Gestión del conocimiento y su incidencia en el capital intelectual de las instituciones de educación superior de la zona 4 del Ecuador, desde el año 2013-2016. (Tesis Doctoral). Lima, Perú (Universidad Nacional Mayor de San Marcos).

Joia, L. (2001). Medindo o Capital Intelectual. RAE. Revista de Administração de Empresas, 41 (2), 54-63.

Kaplan, R., \& Norton, D. (1992). Model Balanced Business Scorecard. Retrieved from http://ascanio.blogspot.com/2007/05/balancedb usiness-scorecard.html

Leif Edvinsson. (1998). El Capital Intelectual: cómo identificar y calcular el valor inexplotado de los recursos intangibles en una empresa. Colombia: Norma.

Marin, F. (2001). El capital intelectual como activo organizacional . Espacio abierto, 10 (3), 409-430.

Mesquita, F., \& Cañibano, L. (2006). Midiendo el capital intelectual de las empresas: propuesta de dos proxies. Revista de Administração $e$ Contabilidade da Unisinos, 297-310.
Muñoz, E. (2019). Estudio de caso, aplicación del "Modelo Intellectus" y aproximación a la gestión del acpital intelectual en una empresa industrial y comercial de Popayán-Cauca en el II semestre de 2018. (Tesis de Maestría). Popayán, Colombia, Universidad Cooperativa de Colombia. .

Nevado D, López V. (2002). El Capital Intelectual: Valoración y medición. ALHAMBRA, S.A.

Norton, R. K. (2000). Cuadro de Mando Integral . In R. K. Norton. Barcelona: Gestió 2,0.

Ortiz, M. (2003). Medición y Auditoría del Capital Intelectual. En el profesional de la información, 12 (4), 285-289.

Pacheco, C. (2009). La administración del capital humano: una estrategia de productividad. Contadurái Pública, 34-37.

Pérez, D., Pelayo, F., \& Añez, L. (2016). Fomento del Capital Intelectual en la PyME. Science of Human Action, 1(2), 211-221.

Roos J, Roos G,Dragonetti N y Edvinsson . (2001). Capital Intelectual . Buenos Aires: Paidós.

Saavedra, M. L., \& Saavedra, M. E. (2012). Una propuesta de medición e incorporación del capital intelectual en la información financiera: el caso de Unión Febre. Cuadernos de Contabilidad, 13 (33), 505-526.

Scarabino, J., Biancardi, G., \& Blando, A. (2007). Capital Intelectual. Invenio, 10(19), 5971.

Scarabino, J., Biancardi, G., \& Blando, A. (2007). Capital Intelectual. Invenio, 10 (19, 5971.

Secretaría de Economia. (2009, junio 25). Diario Oficial de la Federación. Retrieved from http://dof.gob.mx/nota_detalle_popup.php?codi go $=5096849$

SKANDIA . (1996, Junio 02). Supplement to the Annual Report , Customer Value, . Retrieved from www.skandia.com

Stewart, T.A. (1998). La nueva riqueza de las organizaciones: El Capital Intelectual . Buenos Aires, Argentina: Granica .

ORTIZ-CARRANCO, Araceli, RAMIREZ-ROSAS, José, ARROYODIAZ, Salvador and LOZADA LECHUGA, Jorge. Evaluation of intellectual capital in a SME in the city of Puebla, Mexico; applying the Skandia model. Journal-Microeconomics. 2019 
Sveiby, K. (1997). The new organizational wealth: Managing and measuring knowledgebased assets. Nw York: Berrett-Koehle. .

Tejedo, F., Ferraz, J., \& Emmendoerfer, M. (2017). Mecanismos de gobierno corporativo y capital intelectual. REVISTA BRASILEIRA DE GESTÃO DE NEGÓCIOS 19 (65), 394-414, http://dx.doi.org/10.7819/rbgn.v19i65.3024 .

Vidal, C. (2017). Modelo de capital intelectual para la investigación en las. Revista Actualidades Investigativas de Esucación, 71-1, 1-27,

http://dx.doi.org/10.15517/aie.v17i1.27332.

Zuluaga, C. (2019). Capital intelectual de la institución de educación superior CINOC: Contribuciones para la gestión del conocimiento. (Tesis de Maestría). Manizales (Universidad Autónoma de Manizales). 